\title{
Fed batch production of hydrogen from palm oil mill effluent using anaerobic microflora
}

\begin{abstract}
Anaerobic production of hydrogen from palm oil mill effluent (POME) by microflora was investigated in 5-1 bioreactor at $60{ }^{\circ} \mathrm{C}$ and $\mathrm{pH}$ 5.5. POME sludge was collected from the anaerobic pond of a POME treatment plant at a palm oil mill and used as a source of inocula. A batch reactor was found to yield a total of $4708 \mathrm{ml} \mathrm{H} 2 \mathrm{H} 2 /(1 \mathrm{POME})$ and the maximum evolution rate was $454 \mathrm{ml}-\mathrm{H} 2 \mathrm{H} 2 /(1 \mathrm{POME} \mathrm{h})$. A fed batch process was conducted after $50 \mathrm{~h}$. Two liters of reaction medium was removed and 21 of fresh POME was added to the reactor every $24 \mathrm{~h}$ (15 times). The reproducibility of the fed batch process checked by changing the feeding time every $8 \mathrm{~h}$ (10 times). A yield of $2382 \mathrm{ml} \mathrm{H} 2 \mathrm{H} 2 /(1 \mathrm{POME})$ and $2419 \mathrm{ml} \mathrm{H} 2 \mathrm{H} 2 /(1$ POME) at maximum evolution rate of $313 \mathrm{ml} \mathrm{H} 2 \mathrm{H} 2 /(1 \mathrm{POME} \mathrm{h})$ and $436 \mathrm{ml} \mathrm{H} 2 \mathrm{H} 2 /(1 \mathrm{POME}$ h) were obtained, respectively. Throughout the study, methane gas was not observed in the evolved gas mixture.
\end{abstract}

Keyword: POME; POME sludge; Production of hydrogen; Microflora 